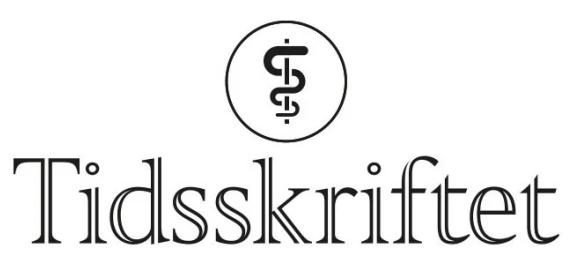

DEN NORSKE LEGEFORENING

\title{
Merkelig om diagnoser
}

\author{
KOMMENTAR
}

EIRIK HORNES HALVORSEN

eirhal@siv.no

Eirik Hornes Halvorsen er radiolog.

Forfatteren har ikke oppgitt noen interessekonflikter.

Intervjuet med sosiolog Berit Bringedal i Tidsskriftet nr. 1/2021 (1) inneholder mange interessante poenger. Men én setning, som Tidsskriftet har valgt å fremheve i teksten, er merkelig: «Diagnoser er ikke objektive sannheter, de skapes i møtet mellom pasient og lege».

Vi som daglig jobber med medisinsk diagnostikk vil som regel ha motsatt utgangspunkt, nemlig at diagnoser skal være så objektive og sanne som mulig. Det gjelder enten vi diagnostiserer for eksempel kreft, lungeemboli, appendicitt eller covid-19. Jeg tror alle, ikke minst pasientene, er tjent med at det også gjelder diffus muskel- og skjelettsykdom og depresjon, som brukes som eksempler på diagnoser i intervjuet.

Objektiv, sann og presis diagnostikk er grunnleggende for det aller meste som skjer i helsevesenet. Det er vanskelig å forstå hva som menes med at diagnoser «skapes i møtet mellom pasient og lege». Og hvis diagnoser ikke er objektive sannheter, hva er de da? Subjektive usannheter?

\section{LITTERATUR}

1. Reymert J. Kunsten å prioritere. Tidsskr Nor Legeforen 2021; 141. doi: 10.4045/tidsskr.20.0847. [CrossRef]

Publisert: 22. februar 2021. Tidsskr Nor Legeforen. DOI:10.4045/tidsskr.21.0o81

(C) Tidsskrift for Den norske legeforening 2023. Lastet ned fra tidsskriftet.no 26. april 2023. 